\title{
KONSEKUENSI INOVASI ORGANISASI TERHADAP PERAN PR
}

\author{
Melati Tobing \\ ohmelati@yahoo.com
}

\begin{abstract}
The increasing levels of competition that emerged in the community, led the organization to keep pace. It can only be achieved if the organization want to follow the changes, by doing innovation. In doing that, an organization often have to face problems that cause stagnation in the innovation process and leads to the trauma of innovation. Those obstacles which are not rare also happened to the communication's activity. Therefore the role of leadership in the organization is very important especially on how to communicate reliably. Nevertheless, a public relations strategically can support its leader in achieving innovation by acting effectively as a mediator, which is always communicate with external public and mainly with the internal's public of the organization itself.
\end{abstract}

Keywords: Organizational Innovation, Communication, Role of Public Relations

\section{Perlunya Inovasi dalam suatu Organisasi}

Beberapa perusahaan atau organisasi memandang bahwa inovasi bukan hal yang utama untuk meraih sukses. Perubahan inovasi yang terjadi dalam suatu organisasi menunjukkan bahwa inovasi dalam suatu organisasi tidak terlalu diinginkan, mengkhawatirkan, dan bukan sebagai prioritas utama. Inovasi dalam suatu organisasi dianggap perlu tetapi tidak penting, dan juga dianggap merupakan pekerjaan orang lain atau bukan bagian dari pekerjaan yang mesti dilakukan oleh orang-orang yang saat itu berada di dalam organisasi.

Setiap organisasi mempunyai pandangan yang berbeda terhadap perlunya suatu inovasi, hal ini disebabkan adanya perbedaan konteks dan hambatan yang akan dihadapi dalam setiap organisasi. Sejumlah buku dan tulisan mengenai kehumasan menekankan bahwa pimpinan organisasi memegang peranan penting dalam inovasi, terutama terkait dengan masalah komunikasi. Untuk menyelesaikan perbedaan konteks dan hambatan dalam upaya inovasi organisasi itulah diperlukan peran pimpinan untuk mengidentifikasi dan mengomunikasikannya. Sebelum mengambil suatu inovasi, seorang pimpinan organisasi sebaiknya dapat menentukan terlebih dahulu strategi, perencanaan dan visinya.

Inovasi bukan hanya pengembangan teknologi semata, karena ilmu pengetahuan yang berdiri sendiri bukanlah teknologi dan teknologi yang berdiri sendiri juga bukanlah pengetahuan, keduanya saling bersentuhan (Morita, 1992). Dari apa yang dikatakan Morita menunjukkan arti penting dari suatu perubahan 
yang diakibatkan oleh inovasi. Hal ini tidak cukup dilihat dari sisi keuangan atau materiil saja, namun harus lebih melihat pada semua sisi kehidupan manusia, baik dari segi struktur sosialnya maupun budaya dan gaya kepemimpinan yang ada dalam masyarakat tersebut. Kepemimpinan yang baik adalah kunci dari keberhasilan suatu inovasi, namun tanpa dukungan proses yang baik dan strategi yang jelas, maka kita tidak pernah bisa mencapai apa yang diharapkan dari suatu inovasi.

Dalam proses inovasi di suatu organisasi, biasanya tidak datang dari penemuan penelitian atau pengembangan laboratorium, namun merupakan suatu mandat yang harus direncanakan dari atas dengan mengidentifikasikan tujuan dan prioritas. Hal ini dapat dilakukan dengan cara menginformasikan ke seluruh bagian atau individu yang ada dalam organisasi tersebut. Inovasi seperti ini akan berhasil apabila lingkungan mendukung, kesamaan tujuan dan adanya perasaan yang sama dari setiap orang bahwa mereka berada dalam satu kapal yang sama. Apabila kapal tenggelam maka mereka pun akan hanyut di dalamnya.

Menciptakan inovasi dalam suatu kelompok tidaklah mudah, namun harus dilakukan apabila kita menginginkan perkembangan suatu organisasi. Pentingnya inovasi merupakan kunci untuk mencapai suatu perubahan yang lebih baik (Peters, 1980). Mengapa? Karena semakin banyaknya persaingan atau kompetisi yang muncul dalam masyarakat kita, yang menyebabkan kita harus tetap bertahan. Hal itu hanya bisa dilakukan dan dicapai apabila organisasi kita mau mengikuti perkembangan yang ada.

\section{Hambatan Komunikasi dalam Inovasi Organisasi}

Dalam melakukan inovasi, suatu organisasi seringkali mengalami hambatan yang menyebabkan kemandekan proses inovasi. Kemandekan inilah yang seringkali menyebabkan munculnya trauma inovasi, sehingga menimbulkan keengganan individu organisasi dalam melakukan inovasi. Hambatan tersebut seringkali ada dalam kegiatan komunikasi. Menurut Dahama dan Bhatnagar (1988), ada tiga jenis hambatan komunikasi inovasi, yaitu:

1. Hambatan teknis, yaitu hambatan yang berhubungan dengan ketepatan mentransfer informasi (noise).

2. Hambatan semantik, yaitu perbandingan interpretasi antara sumber dan penerima terhadap isi pesan inovasi.

3. Masalah-masalah keefektifan, yaitu berbagai hal yang berhubungan dengan keberhasilan transfer atau pengiriman makna kepada penerima.

Untuk mengetahui mengenai hambatan komunikasi dalam inovasi tersebut, maka perlu kita tinjau pandangan Lasswell mengenai Model Proses Komunikasi. Harold Dwight Lasswell, seorang ilmuwan Amerika menjelaskan bahwa cara yang paling sesuai untuk mendefinisikan tindakan komunikasi adalah melalui jawaban pertanyaan berikut: 
- Who

- Says What

- In Which Channel

- To Whom

- With what effect

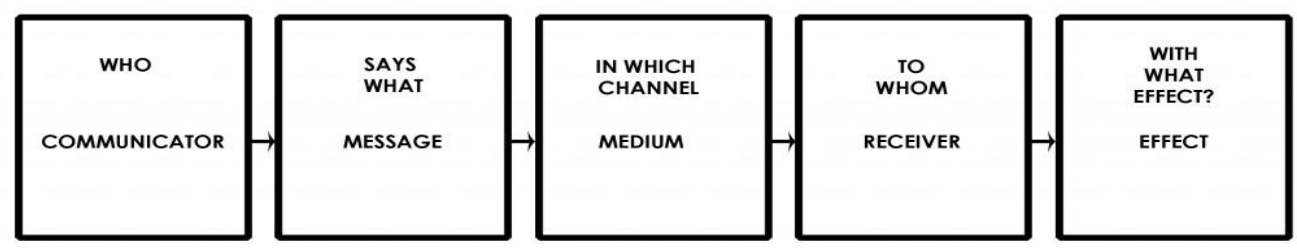

Gambar 1. Formula Lasswell

Sumber: http://communicationtheory.org/lasswells-model/comment-page-1

Hambatan komunikasi dapat terjadi dalam setiap bagian dalam langkah proses komunikasi Lasswel tersebut. Namun, Dahama dan Bhatnagar juga menyatakan bahwa hambatan komunikasi inovasi dapat berasal dari: 1). Sumber pesan, 2). Isi pesan, 3). Penerima Pesan atau hambatan alam.

Hambatan komunikasi yang berasal dari sumber pesan, misalnya: nilainilai budaya dan organisasi sosial yang berbeda antara sumber pesan dan penerima pesan; penggunaan simbol-simbol komunikasi yang tidak tepat; sumber pesan memiliki konsep yang salah tentang komunikasi; proses berlangsungnya komunikasi inovasi tidak teratur/ tidak terencana; serta sumber pesan tidak menyusun atau memiliki pedoman tertentu untuk memperbaiki proses komunikasi yang dijalankannya.

Hambatan komunikasi yang berasal dari saluran komunikasi, antara lain: kekeliruan menggunakan media komunikasi; kesalahan pemilihan media; gangguan fisik, misalnya kerusakan media yang digunakan. Sedangkan hambatan komunikasi yang berasal dari penerimaan pesan antara lain: tidak ada perhatian dari penerima pesan terhadap kegiatan komunikasi yang sedang berlangsung dan tentunya termasuk isi pesan yang disampaikan oleh sumber pesan; penerima pesan tidak dapat bekerja sama dengan sumber pesan dan tidak mau berpartisipasi dalam kegiatan komunikasi yang sedang berlangsung; tidak bersikap positif terhadap sumber pesan, misalnya curiga atau tidak menyimak sumber pesan.

Hambatan komunikasi yang berasal dari isi pesan atau inovasi yaitu: Inovasi tidak memiliki keuntungan relatif (relative advantage) yang dapat ditawarkan kepada khalayak, misalnya keuntungan ekonomis, sosial, atau 
peningkatan status sosial terutama dalam jangka panjang; inovasi yang dibawa oleh sumber pesan ternyata bertentangan (incompatible) dengan adat istiadat, nilainilai yang telah ada, tatanan sosial, sistem kepercayaan, atau cara hidup khalayak; inovasi yang disampaikan sangat rumit (complexity) sehingga sulit dipahami penerima pesan; Inovasi tidak dapat disebarluaskan terlebih dahulu (untrialibility) dalam skala kecil sebelum disebarluaskan ke masyarakat luas; hasil tidak dapat dilihat secara langsung (unobservability) sehingga sulit dipercaya masyarakat jika tidak melihat sendiri.

\section{Dinamika Keseimbangan dalam Konsekuensi Inovasi}

Konsekuensi akan terjadi apabila ada suatu hasil yang diakibatkan oleh adanya inovasi, baik itu konsekuensi yang berupa penolakan, maupun penerimaan. Konsekuensi akibat adanya hal baru tersebut bisa terjadi secara spontan maupun perlahan. Namun untuk memperkirakan kapan akibat konsekuensi tersebut terjadi adalah hal yang sulit dipastikan. Hal ini dikarenakan pemahaman suatu konsekuensi baru dapat dipelajari setelah terjadinya penyebaran suatu inovasi. Lebih sulitnya lagi, bahwa suatu konsekuensi bisa terjadi jauh setelah proses pengadopsian inovasi itu sendiri.

Akibat dari suatu inovasi dapat dikelompokkan dalam tiga kategori:

1. Konsekuensi yang diinginkan (desirable consequnce) adalah akibat dari inovasi yang langsung menerpa individu atau sistem sosial, dimana akibatnya memang sudah diprediksi atau diinginkan akan terjadi. Ada jenis inovasi yang tidak memberikan akibat menyenangkan bagi hampir setiap orang yang ada dalam suatu sistem sosial, karena ternyata hal baru tersebut hanya menguntungkan bagi segelintir orang saja. Atau suatu inovasi yang berjalan dengan baik dan mempengaruhi suatu sistem tetapi tidak berdampak kepada individu tertentu sebagai penerimanya. Sekelompok orang yang sulit menerima konsekuensi itu disebut laggard dan biasanya mereka dipengaruhi oleh adanya tekanan ekonomi, maka dalam memberikan inovasi harus dilihat dari segi keuntungan (windfall) yaitu peningkatan pendapatan bagi mereka yang mengadopsi suatu inovasi.

2. Pemisahan antara konsekuensi yang menyenangkan dengan yang tidak menyenangkan selalu ada dalam setiap penyebaran inovasi. Hal ini bisa dimengerti karena setiap orang tidak mau menerima inovasi yang merugikan.

3. Konsekuensi langsung dan tidak langsung. Yang dimaksud dengan konsekunsi langsung adalah perubahan individual atau sistem sosial yang terjadi dengan segera sebagai akibat adanya inovasi. Sedangkan konsekuensi tidak langsung adalah perubahan individu atau sistem sosial sebagai akibat dari adanya perubahan setelah diterimanya suatu inovasi. 
4. Konsekuensi yang dapat diantisipasi dan yang tidak dapat diantisipasi dan yang tidak dapat diantisipasi, adalah suatu bentuk akibat dari suatu inovasi yang dampaknya dapat diperkirakan atau sebaliknya. (modul hal.5.7)

Konsekuensi inovasi, apapun bentuknya akan menghasilkan tiga bentuk keseimbangan, yaitu:

1. Stable Equilibrium, adalah konsekuensi inovasi yang sifatnya stabil. Artinya konsekuensi yang ada bertahan lama dan tidak berubah-ubah, sehingga memberikan kesimbangan yang tetap. Tidak ada perubahan yang menghasilkan ketimpangan bagi masyarakatnya. Karena dengan adanya keseimbangan yang tetap terjaga, menunjukkan bahwa inovasi tersebut dapat memberikan arti yang sangat positif bagi kehidupan kita.

2. Dynamic Equilibrium, adalah konsekuensi yang sifatnya akademis, yang akan memberikan keseimbangan secara bergantian. Artinya perubahan yang dihasilkan sifatnya tidak menetap dan tidak bertahan lama.

3. Disequilibrium, adalah konsekuensi yang sifatnya tidak seimbang. Di sini akibat yang dihasilkan berat sebelah. Menciptakan suatu inovasi yang tidak seimbang akibatnya jauh lebih mudah daripada membuat akibat yang tidak seimbang.

Dalam organisasi, tentu saja kondisi stable equilibrium atau konsekuensi yang stabil dan seimbang dalam waktu yang lama, merupakan hasil keseimbangan yang diharapkan dalam suatu inovasi. Namun demikian, tentu saja keseimbangan tersebut bukan kemudian menyebabkan suatu organisasi enggan untuk melakukan inovasi lanjutan. Sebab mengingat bahwa kompetisi dan persaingan yang terus menerus terjadi.

\section{Public Relations dalam Organisasi}

Posisi PR di dalam organisasi seringkali dapat dijelaskan dengan bagaimana fungsi PR ini muncul di organisasi. Bisa saja PR di dalam organisasi bermula dari awal yang sederhana dan tak disengaja, misalnya diawali dengan orang yang bertugas sekadar membalas surat-surat, menulis laporan tahunan, melayani tamu atau menjalankan tur, mengatur rapat tahunan, dan sebagainya. Setelah perusahaan atau organisasi terus tumbuh, departemen PR mengemban tanggungjawab menjaga hubungan dengan investor dan analisis finansial, agen pemerintah di semua level, kelompok masyarakat, kelompok lingkungan dan kelompok kepentingan lainnya, serta tenaga kerja yang makin beragam.

Dari asal usulnya sebagai tenaga pendukung komunikasi level bawah di dalam departemen SDM, peran PR terus berkembang sampai menjadi bagian integral dari tim manajemen. Akan tetapi agar tetap berada di tim manajemen, PR 
harus memberi kontribusi dalam meraih tujuan organisasi dan menunjukkan akuntabilitasnya berdasarkan hasil yang dapat diukur (Cutlip, 2006:3).

Menurut Onong Uchjana Effendy (2008:212), public relations atau hubungan masyarakat (PR atau humas) didefinisikan IPRA (International Public Relation Asociation) sebagai:

Fungsi manajemen dari sikap budi yang berencana dan berkesinambungan, yang dengan itu organisasi-organisasi dan lembaga-lembaga yang bersifat umum maupun pribadi, berupaya membina pengertian, simpati, dan dukungan dari mereka yang ada kaitannya/hubungannya-dengan jalan menilai opini publik di antara mereka untuk sedapat mungkin mengkorelasikan kebijaksanaan dan tatacara mereka, dengan informasi yang berencana dan tersebar luas, untuk mencapai kerjasama yang lebih produktif dan pemenuhan kepentingan bersama yang lebih efisien.

Menurut definisi tersebut, PR adalah fungsi manajemen, yang berarti melekat atau tidak terlepas dari manajemen. Tujuannya adalah untuk membina pengertian (understanding), simpati, dan dukungan (support) dari publik, baik publik internal maupun publik eksternalnya. Bagi seorang manajer/ pimpinan, $P R$ officer adalah pembantu utama dalam bidang informasi dan komunikasi. Ia menilai dan mengomunikasikan informasi dari organisasi dan secara timbal balik ia melihat dan menanggapi informasi yang dikomunikasikan kepada organisasi.

Hal ini juga mengacu pada Quirke (1995:71,75), yang percaya bahwa 'arus ide, informasi dan pengetahuan sekeliling organisasi itu penting bagi kesuksesan. Aturan komunikasi sebagai suatu proses yang mengalir diterima sebagai pusat manajemen organisasi', maka komunikasi menjadi bagian penting dalam setiap kegiatan organisasi. Lebih lanjut ia menjelaskan:

A business can only achieve its best when everyone's energies are pointed in the same direction and are not at cross-purposes. Employees need to have a clear picture of the overall direction and ambitions of the company (and) a clear sense of where he or she fits in and how (they) contribute to the company's goals.

Seorang PR handal dapat melakukan teknik-teknik komunikasi untuk merekayasa jiwa publik, misalnya yang terkait dengan mengubah sikap, opini atau perilakunya. Ia juga akan mampu mencegah timbulnya erosi citra atau reputasi negatif dari publik terhadap organisasi (Onong, 2008:213). Karenanya, seringkali PR dikaitkan dengan reputasi,- yaitu hasil apa yang saya lakukan, saya katakan, dan orang lain katakan tentang saya, hal mana dikemukakan oleh Johana Fewkes (2008:5) sejalan dengan The Chartered Institution of Public Relations (CIPR) atau lembaga tertinggi profesional dari para praktisi PR se-Inggris.

Public relation dalam organisasi memiliki fungsi sebagai mediator di dalam maupun di luar organisasi. Publik internal adalah publik yang berada di dalam organisasi. Menurut Rhenald Khasali (2005:11), publik internal tersebut adalah karyawan, satpam, penerima telepon, supervisor, klerk, manajer, para pemegang 
saham, dan sebagainya. Sedangkan publik eksternal adalah mereka yang berkepentingan terhadap perusahaan dan berada di luar organisasi, misalnya: penyalur, pemasok, bank, pemerintah, komunitas dan pers.

Profesional PR mendukung sub-sistem internal lain dengan membantu mereka berkomunikasi dengan organisasi itu sendiri dan dengan khalayak eksternal (Gregory, 2008: 52). Fungsi PR dalam organisasi dapat dilihat dari gambar berikut:

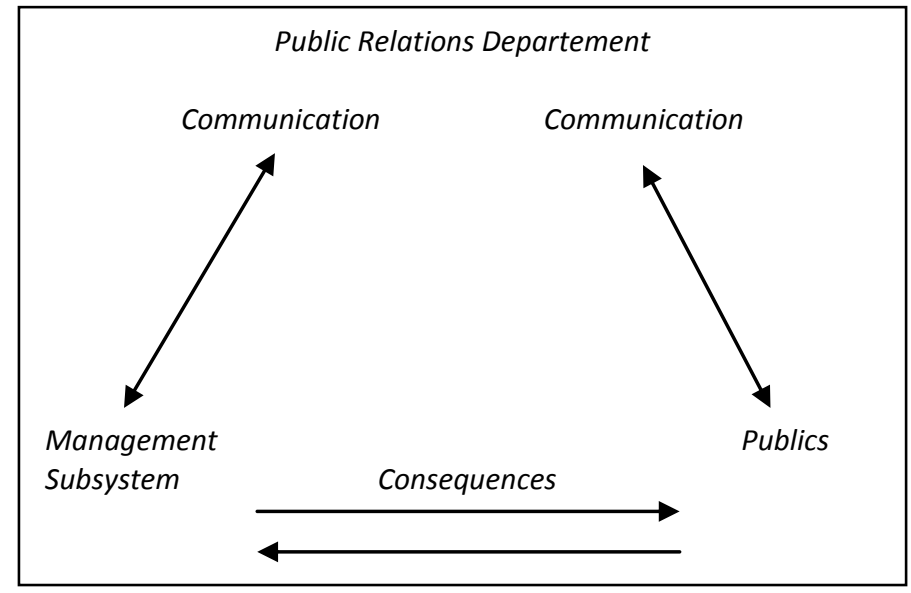

Gambar 2. Fungsi Public Relations dalam suatu Organisasi

Sumber: Grunig and Hunt (1984) dalam The Public Relation Handbook, London: Routledge, 2008:52

\section{Peranan PR Internal dalam Inovasi Organisasi}

Dalam kaitannya dengan inovasi, seorang PR memiliki peran penting dalam membantu pimpinan untuk mengomunikasikan strategi, tujuan dan visi organisasi yang baru terutama kepada publik internal. Memahami dengan tepat kata "publik" akan memudahkan PR dalam berperan dalam kegiatan inovasi.

Publik dalam PR berarti suatu kelompok orang yang memiliki kebutuhan informasi berbeda dan permintaan keinginan yang berbeda terhadap organisasi. PR profesional mendorong sub-sistem internal dengan membantunya berkomunikasi dengan organisasi itu sendiri maupun khalayak eksternalnya. Namun demikian, mengingat kompleksitasnya hanbatan inovasi dalam internal organisasi maupun publik internalnya, maka ada baiknya apabila kegiatan inovasi diterapkan terlebih dahulu pada sub-sistem internal. Setelah berhasil, kemudian dilakukan pada sub-sistem eksternal. Karena itulah, pembahasan selanjutnya akan lebih menekankan pada peranana PR internal dalam kegiatan inovasi suatu organisasi. 
Menurut Richardson dan Laville (Richardson, 2010: 98), kunci strategis yang dapat mempengaruhi komunikasi internal mencakup:

- Supporting major change

- Communicating messages from the management

- Communicating the business's mission or vision or values

- Raising awareness of business issues and priorities

- Increasing and maintaining the credibility of the management

- Motivating employees

- Allowing feedback from staff

- Improving the communication skills of management

Untuk dapat berkomunikasi secara efektif diperlukan pemahaman tentang strategi inovasi secara keseluruhan sehingga visi tersebut dapat dibagikan oleh PR organisasi kepada staf dan mereka dapat membantu mencapainya. Dengan sedikit usaha dari manajemen/ pimpinan untuk membantu mereka memahami aturan untuk berkontribusi pada "gambaran besar", staf akan bangga dalam melakukan pekerjaannya, sehingga memberikan keuntungan bagi organisasi.

Di tahun 1996, McElreath (Fawkes, 2008:6)) menjelaskan ada dua hal yang dapat disimpulkan dalam menjalankan praktek PR, yaitu: teknisi atau pemecahmasalah. Praktek teknisi PR seperti mengetik surat maupun melayani wartawan dan publiknya, tentu saja diperlukan dalam kegiatan inonasi. Namun fungsi PR sesungguhnya adalah menyelesaikan masalah komunikasi yang dapat menghambat tercapainya tujuan dan sasaran inovasi organisasi. Salah satu dari kegiatan pemecahan masalah itu misalnya adalah dengan melakukan komunikasi top-down, yaitu mengomunikasikan pesan dari pihak manajemen kepada karyawan, sehingga memperoleh empati dan dukungan.

Hal yang paling efektif untuk memperoleh pemahaman dan empati dari staf adalah melalui suatu audit. Perlu diketahui apa yang pekerja pahami tentang inovasi dan identifikasi kesenjangan pengetahuannya, serta keterikatan moral dan motivasinya. Kegiatan audit komunikasi inovasi ini dapat dilakukan melalui metode diskusi fokus grup, kuesioner atau tim rapat. Setelah dilakukan audit, maka data yang terkumpul dapat dievaluasi untuk mengetahui pemahaman maupun ketidakpuasan karyawan. Informasi yang terkumpul ini akan mengidentifikasikan pola-pola serta ketidakkonsistenan yang mesti diarahkan secara positif. Kegiatan audit dapat dilakukan secara teratur, dengan kerelaan partisipan. Untuk memaksimalkan partisipasi, seorang PR dituntut untuk dapat bertindak cepat terhadap rekomendasi dan komentar karyawan. Isue negatif yang berkembang dipendam dengan menjelaskan sekilas hasil audit. Kritik negatif yang muncul mesti diarahkan untuk mendapat hasil yang positif untuk menjaga ketetapan hati.

Dalam melakukan audit komunikasi inovasi, seorang PR bisa saja mendapatkan respon yang tidak disukainya, namun demikian hal tersebut harus disikapi secara profesional. Isue yang berkembang tidak baik bila diabaikan, setiap 
orang akan menghargai tanggapan terhadap issue yang berkembang, sehingga perlu dihadapi langsung secara bijak. Hal ini dapat mendatangkan komitmen positif dari karyawan.

Dalam kegiatan komunikasi internal, seorang PR perlu memastikan bahwa manajemen senior dapat melakukan komunikasi dengan karyawan baik langsung maupun melalui berbagai media internal. Majalah perusahaan misalnya, dapat mengeluarkan publikasi mingguan, bulanan atau dalam waktu tertentu yang reguler, yang berisi pesan khusus dari pimpinan. Isinya juga memuat pencapaian prestasi dari semua publik internal, baik secara profesional dan personal. Media internal yang menarik penuh dengan warna dan mudah dibaca, dengan berbagai foto yang melengkapi tulisan dan ilustrasi artikel. Selain itu, media lain yang juga dapat dipergunakan dalam kegiatan komunikasi internal adalah intranet, event dan rapat, papan pengumuman, ruang-ruang tempat berkumpul dan internet atau website organisasi (Richardson, 2010: 103-106).

Website organisasi saat ini menjadi bagian penting dalam komunikasi internal maupun eksternal organisasi. Sayangnya, pemanfaatan website masih cenderung mengarah pada publik eksternal saja, padahal media tersebut memiliki prospek strategis dalam berkomunikasi dengan publik internal.

Hal-hal dasar yang dibutuhkan karyawan dalam kegiatan komunikasi yang baik adalah mencakup:

- Informasi umum tentang organisasi

- Informasi khusus tentang aturan organisasi

- Kejelasan aturan

- Penjelasan tentang visi organisasi

- Informasi tentang lokasi organisasi

- Peluang bergabung dan konsultasi

- Respon dari kinerja

- Akses untuk training dan pengembangan

- Akses untuk berbagai saluran komunikasi lainnya.

Pada tahun 1964, C.J. Dover menjelaskan tiga hal dari 'empat masa' komunikasi karyawan pada model PR-nya (Theaker, 2008: 231), yaitu:

1. The era of entertaining employees (tahun 1940-an)

2. The era of informing employees (tahun 1950-an)

3. The era of persuasion (tahun 1960-an)

Kemudian Grunig dan Hunt (1984) menambahkan yang ke-empat:

4. The era of open communication (two-way asymmetric)

Jika kita menyetujui pendapat Grunig dan Hunt tersebut, maka tidak perlu diragukan lagi bahwa keberhasilan suatu organisasi tidak akan terlepas dari 
kemampuan fungsi PR-nya dalam menjalankan upaya komunikasi yang terbuka dan bersifat dua arah. Dalam prakteknya, kegiatan komunikasi terbuka ini tentu saja harus mempertimbangkan berbagai hal seperti konteks bisnis organisasi ataupun budaya organisasi yang ada.

Berdasarkan survey yang dilakukan Watson Wyatt Company (Cutlip, 2006:257), komunikasi tatap muka dengan "kebijakan pintu terbuka" adalah medium utama mendorong terjadinya komunikasi dua arah ke atas dan membantu menciptakan hubungan kerja yang baik dengan karyawan. Menyeimbangkan kepuasan karyawan dengan kesuksesan usaha adalah salah satu aspek dari penyesuaian dan rekonsiliasi yang terus menerus dilakukan dalam hubungan karyawan-atasan (pimpinan), akan tetapi sebagai bagian dari fungsi PR yang lebih luas, tujuan hubungan internal adalah membangun dan mempertahankan hubungan yang sama-sama bermanfaat antara organisasi dan karyawan, di mana kesuksesan atau kegagalan organisasi akan tergantung kepada karyawan.

Hal lain yang strategis dalam kegiatan komunikasi inovasi organisasi dalam hubungannya dengan peran PR adalah tentang budaya organisasi dan etika karyawan. Pemimpin yang baik dapat menemukan nilai-nilai budaya organisasi dan mampu mengomunikasikannya secara efektif, sehingga memiliki kredibilitas dan kualitas dalam komunikasi internal.

Menurut David Thomas dari Harvard Business School (Ricardson, 2010:106), menekankan pentingnya kemampuan multi dimensi dalam berkomunikasi:

What you say in only the beginning... Your behavior, your actions, and your decisions are also ways of communicating, and leaders have to learn how to create a consistent message through all of these. It's been said many times, but leaders lead by example... Communication can't always follow the top-down model... With the fluidity of information in business today, leaders need to be masterful listeners; they need to be able to receive as well as send. Individuals at all levels of an organization need to be able to take responsibility for their decisions. They've got to feel they have a spehere of influence that allows them to have their own version of enacting the organization's vision and strategy.

Banyak organisasi percaya bahwa karyawan bekerja untuk mendapatkan uang. Penelitian lebih lanjut mengungkapkan bahwa jenis organisasi tempat untuk bekerja lebih penting daripada gaji, bagi banyak responden. Kontrak psikologis antara pekerja dan pimpinan itu kompleks dan berlapis. Karenanya untuk dapat mempertahankan karyawan, diperlukan "kontrak psikologis" baru seperti pelatihan dan pengembangan, selain penggajian yang layak dan pemberian komitmen organisasi lainnya.

\section{Mendengar dan Berbicara untuk Mencapai Tujuan Inovasi}


Dalam kegiatan PR, komunikasi memegang peranan utama. Kegiatan komunikasi PR mencakup mendengarkan dan berbicara, bukan berbicara dan kemudian mendengarkan. Hal ini menjadi penting terkait peran PR sebagai mediator antara kepentingan organisasi yang direpresentasikan oleh pimpinan dan masukan dari karyawan sebagai masukan kepada pimpinan.

Plato telah memahami hubungan antara mendengarkan dan belajar: para murid sekolahnya di zaman Athena kuno dilarang berbicara di sepanjang tahun pertama masa belajar. Kaitan antara mendengarkan dan belajar ini sangat penting bagi bisnis. Menurut Thomas D. Zweifel (2007:33), dalam perusahaan masa kini yang kompleks dan cepat berubah, para CEO sangat bergantung pada informasi strategis dan vital dari orang lain, baik di dalam maupun di luar organisasi. Mendengarkan merupakan sarana yang sangat penting untuk mendapatkan kecerdasasn strategis itu.

Meskipun demikian, mendengarkan menjadi komoditas yang dipandang rendah. Sementara siang dan malam kita dibanjiri oleh iklan dan e-mail yang mendesak kita membeli ini atau mencoba itu. Seringkali, ketika orang menyuruh orang lain "mendengarkan", maksud mereka sebenarnya adalah menyuruh orang lain itu "tutup mulut!" agar mereka bisa berbicara. Khususnya dalam budaya Barat, orang-orang penting berbicara, sementara mereka yang tidak mempunyai sesuatu untuk dikatakan mendengarkan. Mendengarkan tidak menimbulkan suara, tidak memiliki bentuk dan hanya meninggalkan sedikit bukti. Sedangkan berbicara menimbulkan suara, menarik perhatian dan dapat direkam.

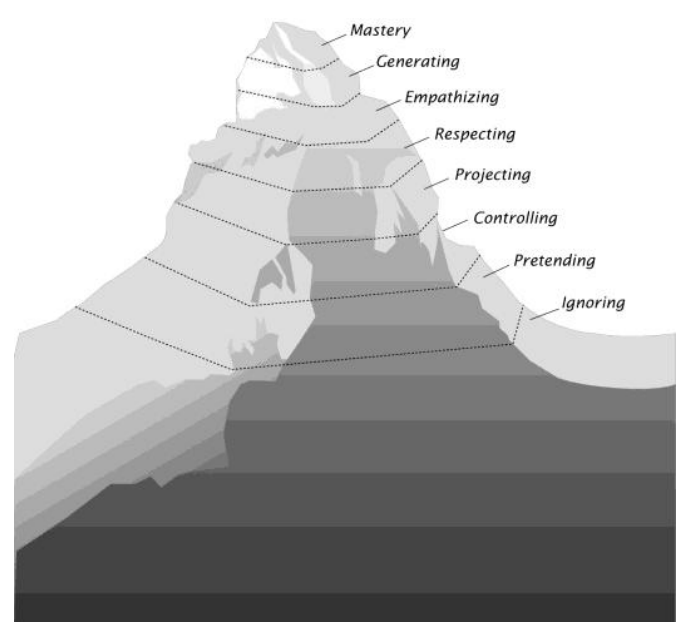

\section{Gambar 3. Matterhorn of Masterful Listening}

Didengarkan berarti kita diperhatikan dengan serius, gagasan dan perasaan kita diketahui, dan akhirnya apa yang harus kita katakan memiliki arti (Michael P., 1995). Hal ini menjadi penting bagi upaya inovasi, sebab ketika diperhatikan dengan serius, maka anggota tim kerja pun akan berkinerja dengan 
sama seriusnya. Ketika seseorang memperlakukan seseorang seseolah kata-kata kita memiliki arti, maka kita pun berfungsi seolah-olah kinerja kita memiliki arti.

Demikianlah perlu dipahami bahwa mendengarkan adalah ungkapan kasih atau bagian dari kasih di dalam kehidupan organisasi. Dalam pepatah Cina untuk mendengarkan, hal ini juga berarti mata, telinga, diri kita, perhatian penuh dan kasih. Praktik mendengarkan yang selaras dengan berbagai makna yang kaya itu bisa menjadi salah satu nilai pengangkat dalam membentuk masa depan organisasi.

Berbicara saja tidaklah mendukung perubahan dan tujuan inovasi. Dengan memilah komunikasi produktif dan kemudian meminimalkan komunikasi tidak produktif, kita akan menjadi pembicara yang pandai membuat kekuatan dan tujuan. Kita pun berada pada jalur menuju penguasaan bahasa: berbicara (atau membuat pesan e-mail, pesan suara, atau berkomunikasi melalui $W e b$ ) dengan cara yang membawa realitas sesuai yang ingin diciptakan. Ada empat dosa besar dalam berbicara, yaitu: 1. Rumor dan Gosip, 2. Penilaian dan Evaluasi, 3. Alasan dan Dalih, 4. Ancaman dan Ultimatum.

Komunikasi produktif memperkuat orang dalam mengatalisasi tindakan serta hasil yang diinginkan. Komunikasi produktif dapat berupa deklarasi atau penegasan, komitmen, permintaan atau undangan, cerita- bahkan humor. Tidak seperti pembicaraan tidak produktif, mode bicara produktif mengarahkan pembicara ke masa depan, bukan masa lalu.

Menurut Thomas Zwefel (2007:35), hal yang perlu disampaikan adalah, komunikasi adalah bagian penting dalam proses inovasi, namun bukanlah sesuatu yang wajib dan perlu dilembagakan atau dijadikan hukum. Komunikasi adalah tujuan, bukan struktur. Orang perlu memiliki hasrat inheren untuk berkomunikasi dengan orang lain. Komunikasi tidak boleh menjadi akhir dalam komunikasi itu sendiri, namun sebagai sarana menuju akhir. Jika ada orang yang bisa memberikan hasil tanpa berkomunikasi, biarkan saja. Tetapi perlu diwaspadai berbagai perangkap yang dapat muncul: jika komunikasi yang ada adalah top-down atau benar-benar kurang, sepertinya organisasi tidak akan mendapatkan inovasinya. Dalam hal ini peran PR menjadi sangat menonjol untuk tetap berkomunikasi, sebab dalam kegiatan inovasi, kegagalan terbesar sesuangguhnya adalah tidak berkomunikasi.

\section{Penutup}

Dalam menjalankan usahanya pada masa kini, organisasi mesti melakukan inovasi agar dapat hidup dan bersaing dengan para kompetitornya di masyarakat. Kegiatan inovasi organisasi memerlukan peran pimpinan yang memiliki kemampuan komunikasi efektif dalam mewujudkan visi misi tujuan dan strategi inovasinya.

Seorang PR dapat membantu pimpinan dalam mengomunikasikan secara efektif maksud dan tujuan inovasinya, baik kepada publik eksternal dan terutama kepada publik internalnya. Namun seringkali upaya inovasi tersebut mengalami 
berbagai hambatan dalam prosesnya. Hal tersebut disebabkan, seringkali suatu perubahan dianggap "kurang menarik" sehingga PR dapat membantu pimpinan terutama dari dalam publik organisasi itu sendiri dalam mengomunikasikan inovasi tersebut. Prinsipnya adalah agar apa yang diinginkan oleh pimpinan dapat tersampaikan dengan benar, dan apa yang diharapkan maupun dirasakan oleh karyawan juga dapat dipahami oleh pimpinan.

Upaya mengatasi berbagai hambatan dalam inovasi organisasi lebih baik dimulai dari publik internal, sehingga PR dapat mendorong proses inovasi organiasi melalui berbagai strategi komunikasi baik melalui komunikasi secara langsung maupun menggunakan berbagai media internal. Pemanfaatan setiap momen untuk mengomunikasikan inovasi organisasi oleh pimpinan, dapat difasilitasi oleh PR. Namun demikian, berbagai media internal organisasi dapat ditingkatkan fungsinya dalam mendukung peran PR tersebut, seperti website yang juga dapat diakses karyawan dan berisi informasi bagi pengembangan karyawan.

Keberhasilan suatu inovasi organisasi memerlukan keterampilan multi dimensi komunikasi, sehingga pimpinan dapat berkomunikasi secara efektif, yaitu dengan memperhatikan aspek budaya organisasi maupun psikologis kebutuhan karyawan. Dalam hal ini PR diharapkan dapat pula mendukung strategi inovasi organisasi melalui kegiatan komunikasi pimpinan tersebut pada publik internalnya dan kegiatan audit komunikasi secara efektif. Melalui peran PR, visi inovasi pimpinan yang semula hanya dibicarakan diharapkan akan dapat dirasakan oleh seluruh komponen organisasi dan kegiatan inovasi organisasi berhasil terlaksana.

Sesungguhnya, sebagai bagian dari peran PR yang lebih luas, tujuan hubungan internal adalah membangun dan mempertahankan hubungan yang sama-sama bermanfaat antara organisasi dan karyawan, di mana kesuksesan atau kegagalan organisasi akan banyak tergantung kepada karyawan. Komunikasi tatap muka dengan "kebijakan pintu terbuka" adalah medium utama mendorong terjadinya komunikasi dua arah ke atas dan membantu menciptakan hubungan kerja yang baik dengan karyawan terutama dalam upaya menjangkau cita-cita inovasi. Menyeimbangkan kepuasan karyawan dengan kesuksesan usaha adalah salah satu aspek dari penyesuaian dan rekonsiliasi yang terus menerus dilakukan dalam hubungan karyawan-atasan (pimpinan). PR berperan penting dalam menyukseskannya, agar organisasi tetap dapat berkomunikasi dan menjadi sarana komunikasi publik organisasi, melalui kegiatan mendengar dan berbicara tentang inovasi organisasi tersebut.

\section{Daftar Pustaka}

Cutlip, Scott M., et al.2006. Effective Public Relations, Jakarta: Kencana.

Effendy, Onong Uchjana. 2008. Dinamika Komunikasi, Bandung: PT. Remaja Rosdakarya. 
Fawkes, Johannna. 2008. "What is Public Relations?" dalam Alison Theaker (ed.) The Public Relations Handbook, London and New York: Routledge.

Gregory, Anne. 2008. "Public Relations and Management" dalam Alison Theaker (ed.) The Public Relations Handbook, London and New York: Routledge.

Hubies, Aida, dkk. 2010. Meteri Pokok Komunikasi Inovasi, cet.3 Ed.2, Jakarta: Universitas Terbuka.

Kasali, Rhenald. 2005. Manajemen Public Relations: Konsep dan Aplikasinya di Indonesia, Jakarta: Pustaka Utama Grafiti.

Nichols, Michael P. 1995. The Lost of Art of Listening: How Listening Can Improve Relationships. New York: Guilford Press.

Quirke, W. 1995. "Internal Communication" dalam N. Hart (ed.) Strategic Public Relations. Macmillan Business Press.

Richardson, Neil dan Lucy Laville. 2010. Develop Your PR Skills, London, UK: The Sunday Times.

Theaker, Alison. 2008. The Public Relations Handbook, London and New York: Routledge.

Zweifel, Thomas D. 2007. Communicate or Die: Mencapai Tujuan dengan Berbicara dan Mendengarkan, Jakarta: PT Gramedia Pustaka Utama. 